\title{
ANALISIS SISTEM INFORMASI YANG SEDANG BERJALAN DAN RENCANA PROYEK E-PROCUREMENT DENGAN PENDEKATAN METODE NEW INFORMATION ECONOMICS
}

\author{
${ }^{1}$ Idris Gautama So; ${ }^{2}$ Devy Listisari Saputri \\ 1,2 Jurusan Manajemen, Fakultas Ekonomi dan Bisnis, Universitas Bina Nusantara, \\ Jln. K.H. Syahdan No. 9, Palmerah, Jakarta Barat 11480 \\ devils_saput2000@yahoo.com
}

\begin{abstract}
PT PLN (Persero) is a state owned which manages the biggest electricity businesses that cover the entire territory of Indonesia. His position is very potential for the Indonesian public life requires that PLN is able to manage the investment means the supply of electricity to customers. This is done with the information systems that support business processes in the body of PLN. PT PLN (Persero) has some application systems, infrastructure, service, and management used to increase the ability of the company. In PLN, there is an application that is capable of supporting PLN to conduct the procurement process is procurement information system (e-procurement). PSI Sub-party service providers as e-procurement to see investment information system (SI) and Information Technology (IT) which is proportional to the amount issued benefits and bottom-line impact for companies and can find out the level of funds / investment budgets and alignment of Information Technology there is a project in accordance with company requirements. Those needs based on business needs and applications currently running in the intersection so as to project better. Based on this, the author proposes to analyze the benefits of information technology investments by using the method of New Information Economics (NIE) that combines the two approaches both financial and non-financial. In the method NIE (New Information Economics) will be used four of the five practices that NIE Strategic Demand / Supply Planning, Innovation, Prioritization, and Alignment. The results are expected to help the company to allocate investments SI / IT is more appropriate and supports the company's performance, especially in providing added value to the parties concerned.
\end{abstract}

Keywords: new information economics, information technology investment benefits, e-procurement, bottom-line

\begin{abstract}
ABSTRAK
PT PLN (Persero) merupakan BUMN (Badan Usaha Milik Negara) yang mengelola bisnis kelistrikan terbesar yang mencakup seluruh wilayah Indonesia. Posisinya yang amat potensial bagi kehidupan masyarakat Indonesia mengharuskan PLN mampu mengelola investasi sarana penyediaan tenaga listrik kepada pelanggan. Hal tersebut dilakukan dengan adanya suatu sistem informasi yang menunjang proses bisnis dalam tubuh PLN. PT PLN (Persero) memiliki beberapa sistem aplikasi, infrastruktur, service, dan manajemen yang digunakan untuk meningkatkan kemampuan perusahaan. Dalam PLN, terdapat sebuah aplikasi yang mampu mendukung PLN untuk melakukan proses pengadaan yaitu sistem informasi pengadaaan (e-procurement). Pihak SubDit PSI selaku penyedia layanan e-procurement ingin mengetahui investasi Sistem Informasi (SI) dan Teknologi Informasi (TI) yang dikeluarkan sebanding dengan besarnya manfaat dan dampak bottom-line bagi perusahaan serta dapat mengetahui tingkat dana/anggaran investasi dan penyelarasan dari Teknologi Informasi
\end{abstract}


yang ada dengan proyek yang sesuai dengan kebutuhan perusahaan. Kebutuhan tersebut didasarkan pada kebutuhan bisnis dan aplikasi yang sedang berjalan saat ini sehinggga ditemukan titik temu untuk proyek yang lebih baik. Berdasarkan hal tersebut, penulis mengusulkan untuk menganalisis manfaat investasi teknologi informasi dengan menggunakan metode New Information Economics (NIE) yang menggabungkan dua pendekatan baik finansial maupun non-finansial. Dalam metode NIE (New Information Economics) akan digunakan empat dari lima praktik NIE yaitu Strategic Demand/Supply Planning, Innovation, Prioritization, dan juga Alignment. Hasil penelitian diharapkan dapat membantu perusahaan untuk mengalokasikan investasi SI/TI lebih tepat dan mendukung kinerja perusahaan terutama dalam memberikan nilai tambah bagi pihak-pihak yang berkepentingan.

Kata kunci: new information economics, manfaat investasi teknologi informasi, e-procurement, bottom-line

\section{PENDAHULUAN}

Teknologi informasi dan komunikasi yang terus berkembang memberikan berbagai kemudahan bagi banyak dunia usaha dalam meningkatkan kinerja. Manfaatnya yang sangat besar terutama dalam akses informasi secara real-time, menjadikan teknologi sebagai bumerang bagi perusahaan untuk dapat bertahan dalam persaingan bisnis. Dengan menerapkan bentuk e-business yang baik, perusahaan dapat menekan biaya (penghematan biaya) sekaligus dapat meningkatkan pendapatan secara lebih berarti. Salah satu aktivitas bisnis yang berkembang sejalan dengan prinsip $e$ business tersebut adalah proses pembelian yang memegang peranan penting dan perlu pengelolaan yang sangat baik oleh suatu perusahaan. Posisi kegiatan pembelian tidak lagi sebagai pusat biaya (cost center), tetapi berubah menjadi suatu pusat keuntungan (profit center) karena potensi yang terdapat di dalam kegiatan pembelian tersebut. Dengan melakukan penghematan sedikit dalam nilai pembelian akan berpengaruh besar pada peningkatan keuntungan perusahaan.

Secara alamiah, fungsi pembelian merupakan salah satu bagian dasar dan integral dari manajemen perusahaan sehingga perlu adanya suatu perencanaan atas investasi SI/TI dalam mengembangkan fungsi dan peran pembelian (procurement). Investasi terhadap suatu sistem aplikasi akan dilaksanakan oleh perusahaan secara berkelanjutan karena pandangan perusahaan bahwa terdapat hubungan antara biaya SI/TI dengan kinerja ekonomi dalam perusahaan tersebut.Untuk itu perlu adanya suatu pengukuran atas investasi SI/TI terhadap manfaat yang akan dihasilkan bagi perusahaan. Salah satu metode yang tepat adalah dengan metode New Information Economics (NIE), yang menggabungkan dua pendekatan, baik secara finansial maupun non finansial. Tujuan daripada metode tersebut adalah mengukur investasi SI dan TI untuk memaksimalkan dampak pada bottom-line terhadap rencana proyek SI yang akan dikembangkan dalam perusahaan.

\section{Identifikasi Masalah}

Sub Direktorat Proses Bisnis dan Sistem Informasi memiliki beberapa permasalahan terhadap sistem pengadaan yang ada saat ini yakni kurang maksimalnya pelatihan yang diberikan kepada pihak eksternal atau rekanan PLN dan kurangnya kepahaman user terhadap sistem. Berdasarkan hasil kuesioner yang diberikan kepada pihak eksternal bahwa rekanan PLN masih memerlukan pelatihan mengenai penggunaan sistem pengadaan yang benar. User perlu memahami sistem pengadaan terutama mekanisme pengadaan secara elektronis. Selain itu, permasalahan mengenai procurement atau fungsi pengadaan yang bersifat cost center perlu adanya perubahan menjadi profit center dengan upaya pembenahan dari segi fungsional. 


\section{Ruang Lingkup}

Penelitian ditujukan untuk menganalisis biaya dari sistem yang sedang berjalan (Lights On) pada Sub Direktorat Proses Bisnis dan Sistem Informasi, termasuk di dalamnya aplikasi, infrastruktur, service, dan manajemen, serta rencana proyek e-procurement yang akan dikembangkan pada Sub Direktorat Proses Bisnis dan Sistem Informasi. Penelitian yang dilakukan menggunakan metode NIE yang menghasilkan 7 deliverable dari 12 deliverable dalam framework Strategy-to-Bottom-Line Value Chain yaitu Bussiness strategic intention, Assesed Portfolio, Strategic Agenda, Strategic IT Plan, Strategic IT Requirement, Annual and Capital Project Budgets dan Annual Lights-On Budget dengan menggunakan 4 dari 5 praktek manajemen dasar NIE yaitu Strategic Demand/ Supply Planning, Innovation, Prioritization, dan Alignment dan 1 praktek pendukung NIE yaitu Portfolio Management.

\section{Manajemen Pengadaan}

Procurement management (manajemen pembelian) adalah suatu koordinasi seluruh aktivitas yang berhubungan dengan pembelian barang dan jasa yang dibutuhkan untuk melaksanakan misi organisasi (Turban, 2004: 231).

Menurut Davila et al (2003: 4) manajemen seluruh aktivitas pengadaan secara elektronik merupakan fungsi pengadaan yang didukung oleh bermacam-macam bentuk komunikasi secara elektronik.

Menurut Indrajit dan Djokopranoto (anonim3, 2009), bahwa peran pembelian bagi perusahaan dari sudut pandang strategi perusahaan adalah sebagai profit center bagi perusahaan dan sebagai fungsi yang strategis bagi perusahaan. Pertama, sebagai profit center: bahwa fungsi pembelian dengan persentase anggaran yang meningkat untuk pembelian maka keuntungan dapat ditingkatkan apabila pengelolaan pembelian ditangani dengan lebih baik dan lebih profesional. Kedua, sebagai fungsi strategis perusahaan : bahwa fungsi yang ikut menentukan atau sangat berpengaruh dalam penentuan hidup matinya suatu perusahaan.

\section{METODE PENELITIAN}

\section{Metode-metode Procurement}

Menurut Turban (2004: 231), setiap perusahaan memiliki metode yang berbeda dalam membeli barang dan jasa tergantung pada apa dan dimana membeli, kuantitas yang dibutuhkan, berapa banyak yang dibutuhkan, dan sebagainya. Metode yang sering dipakai, antara lain: membeli dari manufaktur, penjual grosir, maupun pengecer dengan melihat katalog dan dilakukan negosiasi, membeli berdasarkan katalog yang diedarkan oleh pihak penyalur atau membeli di pusat industri, membeli dari katalog pembeli internal dimana perusahaan menyetujui katalog-katalog vendor mencakup kesepakatan harga, melakukan penawaran atau tender dari sistem dimana supplier bersaing dengan yang lainnya, metode ini untuk pembelian dalam jumlah besar, membeli di lelang terbuka atau tertutup atau situs pelelangan dimana organisasi berpartisipasi sebagai salah satu pembeli, bergabung dalam suatu grup sistem pembelian dimana permintaan partisipan dikumpulkan sampai dalam jumlah yang besar, kemudian grup menegosiasikan harga atau menginisiasikan sebuah proses tender, bekerjasama dengan supplier untuk berbagi informasi atas penjualan dan persediaan untuk mengurangi persediaan dan stock-out serta mempertinggi ketepatan waktu pengiriman. 


\section{e-Procurement}

Menurut Turban (2004: 232), e-procurement merupakan perolehan barang dan jasa secara elektronis untuk kebutuhan organisasi. Sedangkan Richardus Eko Indrajit (anonim2, 2009) mengemukakan bahwa e-Procurement merupakan suatu mekanisme pembelian masa kini - atau dapat dikatakan sebagai teknik pembelian modern - dengan memanfaatkan sejumlah aplikasi berbasis internet dan perangkat teknologi informasi terkait lainnya sebagai enabler dalam menjalankan proses tersebut. Sementara Davila, et al (2003: 4) menyebutkan e-procurement adalah teknologi yang dirancang untuk memfasilitasi pengadaan barang melalui internet.

\section{Electronic Government Procurement (e-GP)}

Bank Dunia (anonim4, 2009) menyebutkan sebuah definisi dari e-procurement dari segi pemerintahan, yaitu menyatakan bahwa e-GP adalah penggunaan teknologi informasi dan komunikasi khususnya internet oleh pemerintahan-pemerintahan dalam melaksanakan hubungan pengadaan dengan para pemasok untuk memperoleh barang, karya-karya, dan layanan konsultasi yang dibutuhkan oleh sektor publik.

\section{New Information Economics}

Menurut Benson, et al (2004: 99), New Information Economics merupakan sekumpulan praktik yang terkoordinir berdasarkan prinsip dan aktivitas terintegrasi yang secara aktif menghubungkan bisnis dan proses manajemen teknologi informasi dan mampu menghubungkan strategi bisnis perusahaan dengan aktivitas dan inisiatif teknologi informasi. Atau dengan kata lain bahwa NIE (New Information Economics) merupakan pandangan yang lengkap mengenai hubungan unit bisnis dengan teknologi informasi, berdasarkan prinsip utama bahwa semua aktivitas dan sumber daya perusahaan harus mendukung strategi perusahaan dan memberikan dampak pada bottom line. Gagasan dasar dari New Information Economics adalah agar sebuah perusahaan seharusnya melakukan investasi pada teknologi informasi yang secara langsung mendukung strategi bisnis dan operasi yang efisien, dan seharusnya tidak melakukan investasi pada hal-hal yang tidak diperlukan.

\section{Praktek NIE}

Menurut Benson, et al (2004: 9-10), lima praktek NIE menciptakan kumpulan alat untuk TI dan manajer bisnis, mencakup pada proses bisnis untuk menterjemahkan strategi bisnis perusahaan ke program dan inisiatif lainnya yang dapat diimplementasikan TI. Lima praktek tersebut adalah. Pertama, demand/supply planning. Menterjemahkan strategi bisnis ke dalam tahapan yang memberikan arah yang jelas pada TI akan apa yang diharapkan perusahaan (harapan strategi perusahaan). Hasilnya adalah agenda strategi penggunaan TI dalam bisnis yang dapat diubah ke dalam perencanaan dan tindakan TI.

Kedua, innovation. Praktek ini secara explicit menggerakkan manajemen bisnis untuk membuka kesempatan bisnis. yang dimungkinkan oleh TI dan juga menyediakan cara merubah kesempatan tersebut menjadi strategi bisnis dan perencanaan taktik. Hasilnya adalah kumpulan kesempatan bisnis yang kompetitif dan lebih kuat. Ketiga, prioritization. Menganalisa dampak bisnis dari inisiatif TI, memberi prioritas pada proyek, dan menyetujui sumber daya kepada proyek bernilai tertinggi. Hasilnya adalah alokasi uang atau dana yang tepat atas keputusan yang benar dan memungkinkan manajer bisnis dan manajer TI menyetujui keputusan tersebut.

Keempat, alignment. Menganalisa dampak bisnis dari aktivitas TI yang sudah ada. Manajer TI dan bisnis dapat memutuskan inisiatif TI yang manakah yang seharusnya mendapatkan sumber daya perusahaan. Hasilnya adalah pendekatan yang lebih beralasan untuk menghabiskan uang pada aktivitas yang ada, daripada untuk pengembangan baru. Kelima, performance measurement. 
Mengukur kinerja TI dengan cara yang berhubungan dengan bisnis. Sangat mudah untuk menghitung kinerja TI pada tahap operasional dan taktik, tapi sangat sulit untuk mengukur dampak TI pada bisnis. Praktek ini mencampur keduanya dan memungkinkan TI untuk mengetahui apa yang harus diukur, bagaimana mengelola TI berdasarkan ukuran tersebut, dan bagaimana mengkomunikasikan kinerja tersebut kepada manajer bisnis dengan cara yang dapat mereka mengerti. Hasilnya meningkatkan performa TI dan meningkatkan komunikasi dengan manajemen bisnis.

Selain lima teknik utama, NIE juga didukung dengan 3 teknik pendukung, yaitu: pertama, IT Impact Management. Pengelolaan IT Impact terkait dengan salah satu bagian pengelolaan budaya perusahaan dan menawarkan suatu kerangka kerja yang menyatakan hal-hal yang penting bagi perusahaan. Kedua, portfolio management. Pengelolaan portfolio memberikan pertimbangan mengenai seluruh pengeluaran teknologi informasi, menyediakan kerangka kerja untuk menentukan prioritas dan keputusan investasi manajemen. Ketiga, Culture management. Manajemen budaya memungkinkan perusahaan melakukan perubahan yang diperlukan atas budaya yang sedang berjalan agar dapat menghilangkan hambatan saat proses perubahan terjadi.

\section{Tujuan NIE}

Menurut Benson, et al (2004: 68-69), tujuan NIE secara keseluruhan, yaitu: menyediakan kemampuan meliihat $100 \%$ pengeluaran IT, membuat kerangka kerja untuk perencanaan melalui anggaran (mendukung rantai nilai strategi bottom line). Praktek NIE Demand/Supply Planning dan Innovation bertujuan untuk: menghubungkan sumber daya yang ada dan yang dibutuhkan dengan arahan strategi yang ada dalam perusahaan, membuat pondasi untuk mengakses portfolio yang ada dan mendefinisikan portfolio stratgi yang akan datang, menetapkan istilah-istilah yang konsisiten antara bisnis dan TI, menjelaskan kearah mana sumber daya TI akan dipergunakan dan menghubungkannya dengan anggraan dan proses perencanaan perusahaan, menyediakan kerangka kerja untuk mendefinisikan kebutuhan TI, termasuk pembaharuan dan pertumbuhan, menetapkan hubungan dengan pengukuran kinerja. Praktek NIE Prioritization bertujuan untuk menetapkan dasar strategi untuk alokasi dan prioritas sumber daya, menyediakan perspektif untuk kebutuhan investasi yang akan datang, menyediakan dasar untuk melakukan penaksiran resiko dan manfaat proyek. Praktek NIE Alignment bertujuan untuk menetapkan dasar-dasar untuk melakukan layanan, kualitas, keandalan, dan penaksiran resiko, menetapkan informasi beberapa tahun ke depan untuk penyelarasan, menghubungkan $100 \%$ pengeluaran TI pada strategi bisnis TI. Praktek NIE Performance Measurement bertujuan untuk: menyediakan kerangka kerja untuk melakukan pengukuran kinerja dari $100 \%$ pengeluaran TI, menghubungkan pengukuran kinerja dengan perencanaan strategi, menghubungkan kinerja bisnis yang dipengaruhi oleh portfolio TI.

\section{Strategy-to-Bottom-Line Value Chain}

Menurut Benson, et al (2004: 92), Strategy-to-Bottom-line Value Chain merupakan sebuah rangkaian proses manajemen yang terkait dan dijabarkan dalam proyek dan anggaran operasional serta metrik kinerja untuk memantau tindakan dan dampak pada bottom-line. Setiap proses memberi tambahan nilai dari keseluruhan rantai nilai ini, memastikan proses sebelumnya dan apa yang dihantarkan mereka konsisten dan tetap fokus pada strategi bisnis. Hasil pada tahap praktek NIE menghasilkan dasar dan hubungan untuk menghasilkan elemen-elemen rantai nilai ini. Kuncinya, elemen-elemen ini sudah ada pada perusahaan, namun triknya adalah mengkoordinasikan dan menghubungkan mereka melalui praktek NIE. Rantai Nilai Strategi ke Bottom Line :

Pertama, arahan strategi bisnis, merupakan strategi dan perencanaan manajemen untuk meningkatkan efektivitas strategi dan operasional. Setiap arahan strategi perusahaan disertai dengan tujuan, ukuran dan bobot. Arahan strategi bisnis digunakan oleh lima praktek NIE yang isinya adalah misi perusahaan ditambah dengan arahan strategi. Kedua, analisis portfolio. Kumpulan sumber daya 
yang digunakan untuk praktek NIE sebagai alat untuk perencanaan dan pengambilan keputusan sumber daya dan investasi TI. Portfolio aplikasi, infrastruktur, layanan, dan manajemen digunakan untuk menganalisa penyelarasan, layanan, kualitas, teknis, dan intensitas penggunaan. Perkiraan Portfolio digunakan untuk perencanaan dan pengembangan strategi kebutuhan TI melalui proyek. Isinya adalah penyetaraan sebagai-adalah, layanan, kualitas, teknologi, dan intensitas penggunaan setiap aplikasi pada Portfolio.

Ketiga, agenda strategi TI. Agenda sebagai hasil dari strategi perencanaan TI. Strategi agenda TI mendefinisikan harapan bisnis terhadap TI untuk sesuai dengan tujuan strategi bisnis. Strategi agenda TI digunakan untuk menjalankan strategi keperluan TI dan proyek, sebagaimana juga membuat kewajiban pengelolaan bisnis untuk menghasilkan dampak bottom-line dari pengeluaran TI. Isinya Strategic Intention manajemen bisnis untuk penggunaan TI, tujuan strategi untuk penggunaan TI, dan inisiatif strategi TI untuk mencapai Strategic Intention bisnis perusahaan. Keempat, perencanaan strategi TI. Perencanaan ini adalah hasil dari perencanaan strategi TI. Perencanaan ini mendefinisikan hal-hal yang harus dilakukan organisasi TI untuk memenuhi kebutuhan agenda strategi TI. Perencanaan ini digunakan sebagai kerangka strategi anggaran TI yang sedang berjalan dan proyek yang berhubungan dengan teknologi yang dibutuhkan untuk mendukung proyek bisnis. Isinya Strategic Intention organisasi TI untuk mendukung TI memenuhi kebutuhan bisnis yang didefinisikan diatas.

Kelima, kebutuhan strategi TI. adalah pernyataan prioritas dari program dan inisiatif yang selama perencanaan strategi akan memenuhi kebutuhan agenda strategi TI dan strategi intention bisnis. Ini adalah Portfolio inisiatif strategi, dalam jangkauan 3 sampai 5 tahun, untuk mencapai kebutuhan bisnis yang didefinisikan diatas, diprioritaskan berdasarkan Strategic Intention bisnis. Keenam, proyek. Proyek spesifik didefinisikan sebagai respon bagi program dan inisiatif, yang didefinisikan dalam kebutuhan strategi. Proyek adalah kandidat untuk praktek prioritas dan dicantumkan dalam perencanaan proyek tahunan atau anggaran. isinya realistis, proyek yang dapat dilakukan. (bukan merupakan hasil NIE). Ketujuh, perencanaan proyek tahunan. Penencanaan ini adalah kumpulan proyek tahunan yang diharapkan untuk diambil pada tahun fiskal berjalan. Tentu, perspektif proyek "tahunan" tidak tepat waktu atau cukup responsif untuk kebanyakan bisnis, jadi deliverable ini biasanya dievaluasi setiap seperempat tahun ataupun lebih sering untuk beberapa bisnis dinamis. isinya adalah Portfolio dari proyek yang dijadwalkan, dengan sumber daya yang ditetapkan, diprioritaskan berdasarkan Strategic Intention.

Kedelapan, perencanaan bisnis tahunan. Perencanaan ini adalah kumpulan taktik dan perencanaan operasional tahunan untuk unit bisnis. Ini adalah dasar untuk membuat perencanaan proyek tahunan dan mendefinisikan hal-hal yang unit bisnis akan perlukan dari TI. (bukan merupakan hasil NIE). Kesembilan, perencanaan TI. Perencanaan ini merupakan kumpulan perencanaan taktik dan operasional untuk organisasi TI. Perencanaan ini juga merupakan dasar untuk membuat anggaran TI yang sedang berjalan untuk mendukung unit bisnis. Isinya terdokumentasi menurut praktek perusahaan (bukan merupakan hasil NIE). Kesepuluh, anggaran proyek. anggaran proyek adalah kumpulan anggaran investasi untuk proyek tahun itu. Anggaran proyek ini berdasarkan "kemampuan yang dapat diberikan" untuk unit bisnis. Tentu, anggaran ini mungkin berdampak dari kejadian bisnis selama tahun berjalan, dan juga biasanya dievaluasi seperempat tahun sekali atau lebih sering bergantung dari dinamika bisnis. isinya terdokumentasi berdasarkan praktek perusahaan.

Kesebelas, anggaran TI berjalan. anggaran ini merupakan dasar untuk aktivitas organisasi TI tahun berjalan. Anggaran ini menyediakan semua layanan dan dukungan yang tidak disediakan oleh anggaran proyek. digabungkan dengan anggaran proyek, 100\% pengeluaran TI telah didefinisikan. isinya terdokumentasi berdasarkan praktek perusahaan. Keduabelas, pengukuran Kinerja. Pengukuran ini adalah kumpulan ukuran TI dan penggunaan TI dalam bisnis. Isinya terdokumentasi berdasarkan praktek perusahaan. 


\section{HASIL DAN PEMBAHASAN}

\section{Analisis Lingkungan Eksternal}

Analisis yang digunakan adalah analisis PEST. Pertama, politik. Faktor politik yang mempengaruhi pengadaan barang dan jasa yang dikelola oleh SubDit PSI PLN adalah mengenai kebijakan pemerintah akan pengadaan barang dan jasa pemerintah, yakni Keputusan Presiden No. 80 Tahun 2003 yang menetapkan tujuan daripada pengadaan online "Agar pelaksanaan pengadaan dilakukan secaa efisien, efektif, terbuka, dan bersaing, transparan, adil/tidak diskriminatif, dan akuntabel". Peraturan tersebut berpengaruh terhadap proses pengambilan keputusan dalam pengadaan barang/jasa. Dengan kebijakan tersebut diharapkan dapat meningkatkan penggunaan produksi dalam negeri yang mampu bersaing dalam perdagangan internasional. Faktor politik menjadi faktor utama yang berpengaruh terhadap Sub Direktorat Proses Bisnis dan Sistem Informasi.

Kedua, ekonomi. Sub Direktorat Proses Bisnis dan Sistem Informasi berperan dalam menggiring supaya investasi TI PLN berjalan efisien dengan melakukan kelayakan investasi bidang TI baik kajian kelayakan operasional maupun kajian kelayakan finansial PLN. Seringkali dalam kelayakan finansial dipengaruhi oleh faktor fluktuasi nilai tukar mata uang asing. Hal ini dikarenakan investasi TI terkait dengan harga hardware teknologi (barang impor) yang memakai standar dolar. Selain itu untuk kajian investasi, PLN masih sangat tergantung dengan anggaran PLN. Faktor ekonomi lainnya yang mempengaruhi pengelolaan e-procurement oleh SubDit PSI adalah pertumbuhan ekonomi nasional sebesar 5,5\%. Pertumbuhan ekonomi akan berdampak pada peningkatan pasokan listrik sehingga perlu adanya penambahan infrastruktur yang akan dilakukan melalui proses pengadaan.

Ketiga, sosial. Faktor sosial yang mempengaruhi Sub Direktorat Proses Bisnis dan Sistem Informasi PLN adalah hubungan pihak PLN dengan para rekanan PLN baik rekanan di bidang infrastruktur kelistrikan maupun infrastruktur jaringan teknologi. Hubungan baik tersebut mempengaruhi pada proses pengadaan dimana pihak rekanan akan merasa lebih transparan dan adil dengan menerapkan e-Proc yang memungkinkan persaingan terbuka antar vendor. Dengan demikian, persaingan usaha yang sehat dan kompetitif akan menunjang penghematan anggaran belanja.

Keempat, teknologi. Pelaksanaan pengembangan sistem informasi procurement yang dikendalikan oleh Sub Direktorat Proses Bisnis dan Sistem Informasi terkait dengan aplikasi, infrastruktur, dan sumber daya informasi lainnya. Perkembangan teknologi yang selalu berubah mempengaruhi pengembangan aplikasi e-procurement, baik dari segi infrastruktur maupun dari aplikasi itu sendiri. Satu yang dimiliki oleh PLN adalah adanya anak perusahaan (ICON+) yang bertanggung jawab atas ketersediaan infrastruktur jaringan yang kuat dan handal sehingga kestabilan sistem e-procurement dapat terjamin.

\section{Matriks SWOT}

Matriks SWOT diperoleh dari hasil wawancara dan selanjutnya dilakukan analisis terhadap masing-masing faktor internal dan eksternal dengan metode AHP (Analytical Hierarchy Process), sehingga diperoleh beberapa strategi, sebagai berikut. 
Tabel 1 Matriks TOWS

\begin{tabular}{|c|c|c|}
\hline internal & $\begin{array}{l}\text { Strength (Kekuatan) } \\
\text { 1. Perencanaan IT resource korporat } \\
\text { yang baik } \\
\text { 2. Adanya perencana korporat setiap } 5 \\
\text { tahun } \\
\text { 3. Pengembangan proses bisnis secara } \\
\text { terpusat } \\
\text { 4. Adanya aplikasi standar untuk } \\
\text { seluruh proses bisnis } \\
\text { 5. Ketersediaan infrastruktur yang kuat } \\
\text { dan lengkap } \\
\text { 6. Memiliki jasa pendidikan di bidang } \\
\text { sistem informasi }\end{array}$ & $\begin{array}{l}\text { Weakness (Kelemahan) } \\
\text { 1. Keterbatasan dana untuk investasi } \\
\text { 2. Kurangnya SDM } \\
\text { 3. Belum diterapkannya IT Governance } \\
\text { secara menyeluruh } \\
\text { 4. Adanya kontrol yang lemah pada } \\
\text { penerapan IT Governance } \\
\text { 5. Faktor kultur perubahan organisasi } \\
\text { yang cepat } \\
\text { 6. Beberapa unit belum melakukan join } \\
\text { domain dengan pln.co.id }\end{array}$ \\
\hline $\begin{array}{l}\text { Opportunity (Peluang) } \\
\text { 1. Potensi e-Proc berkembang menjadi } \\
\text { portal e-commerce } \\
\text { 2. Aplikasi e-Proc menjadi benchmark } \\
\text { model procurement di BUMN } \\
\text { 3. Kebijakan pemerintah mengenai } \\
\text { pengadaan barang dan jasa } \\
\text { pemerintah } \\
\text { 4. Aplikasi e-Proc digunakan oleh } \\
\text { World Bank untuk setiap pengadaan } \\
\text { 5. Calon penyedia barang/jasa yang } \\
\text { lebih baik dan sesuai } \\
\text { 6. Peluang untuk masuk e-marketplace }\end{array}$ & $\begin{array}{l}\text { STRATEGI SO } \\
\text { 1. Memperluas jaringan rekanan PLN } \\
\text { (penyedia barang/jasa) di seluruh } \\
\text { Indonesia dengan dukungan } \\
\text { teknologi (S1,S2, O3,O5) } \\
\text { 2. Fokus pada pengembangan inovasi } \\
\text { e-Proc yakni menyediakan lahan } \\
\text { untuk promosi barang/jasa dari suatu } \\
\text { perusahaan melalui portal e-Proc } \\
\text { PLN (Persero) (S5, S3, O1) } \\
\text { 3. Fokus pada kebutuhan user eksternal } \\
\text { dengan menjadikan portal e-Proc } \\
\text { menjadi bursa penjualan barang dari } \\
\text { berbagai produsen (S1,S3,O6) } \\
\end{array}$ & $\begin{array}{l}\text { STRATEGI WO } \\
\text { 1. Integrasi ke belakang dengan } \\
\text { melakukan outsourcing atas } \\
\text { pengembangan aplikasi (W2, O2) } \\
\text { 2. Fokus pada penerapan e-procurement } \\
\text { di seluruh unit bisnis PLN dan seluruh } \\
\text { pengadaan (O3, O4, W3, W6) }\end{array}$ \\
\hline $\begin{array}{l}\text { Threats } \\
\text { 1. Pengaruh fluktuasi nilai tukar mata } \\
\text { uang asing } \\
\text { 2. E-Proc belum dipatenkan sehingga } \\
\text { kemungkinan dimanfaatkan oleh } \\
\text { pihak lain } \\
\text { 3. Keabsahan dokumentasi yang belum } \\
\text { diatur oleh Undang-undang } \\
\text { pemerintah } \\
\text { 4. Perubahan atas aplikasi yang } \\
\text { mengikuti perubahan/revisi } \\
\text { kebijakan pemerintah } \\
\text { 5. Peningkatan jumlah eksternal user } \\
\text { dan internal user per tahun } \\
\text { 6. Citra PLN yang belum baik dalam } \\
\text { layanan kelistrikan }\end{array}$ & $\begin{array}{l}\text { STRATEGI ST } \\
\text { 1. Menetapkan hak paten atas aplikasi } \\
\text { e-procurement sebagai hak cipta } \\
\text { PLN (S2, T2) } \\
\text { 2. Fokus pada pengelolaan user dan } \\
\text { aplikasi (S1, S4,S6, T5,T4) }\end{array}$ & $\begin{array}{l}\text { STRATEGI WT } \\
\text { 1. Fokus pada perencanaan dana } \\
\text { investasi teknologi informasi (W1, } \\
\text { T1) } \\
\text { 2. Fokus pada perbaikan kultur } \\
\text { organisasi untuk meningkatkan } \\
\text { kompetensi teknologi dan layanan } \\
\text { kepada pelanggan (W5,W4,T3, T6) }\end{array}$ \\
\hline
\end{tabular}

\section{Matriks Internal-Eksternal}

Matriks IE diperoleh dari total nilai tertimbang internal pada sumbu $\mathrm{X}$ dan total nilai tertimbang eksternal pada sumbu Y. Adapun nilai tertimbang internal (IFE) yang diperoleh adalah 3,0001 dan nilai tertimbang eksternal (EFE) yang diperoleh adalah 3,2617. 
Total Rata-rata Tertimbang IFE

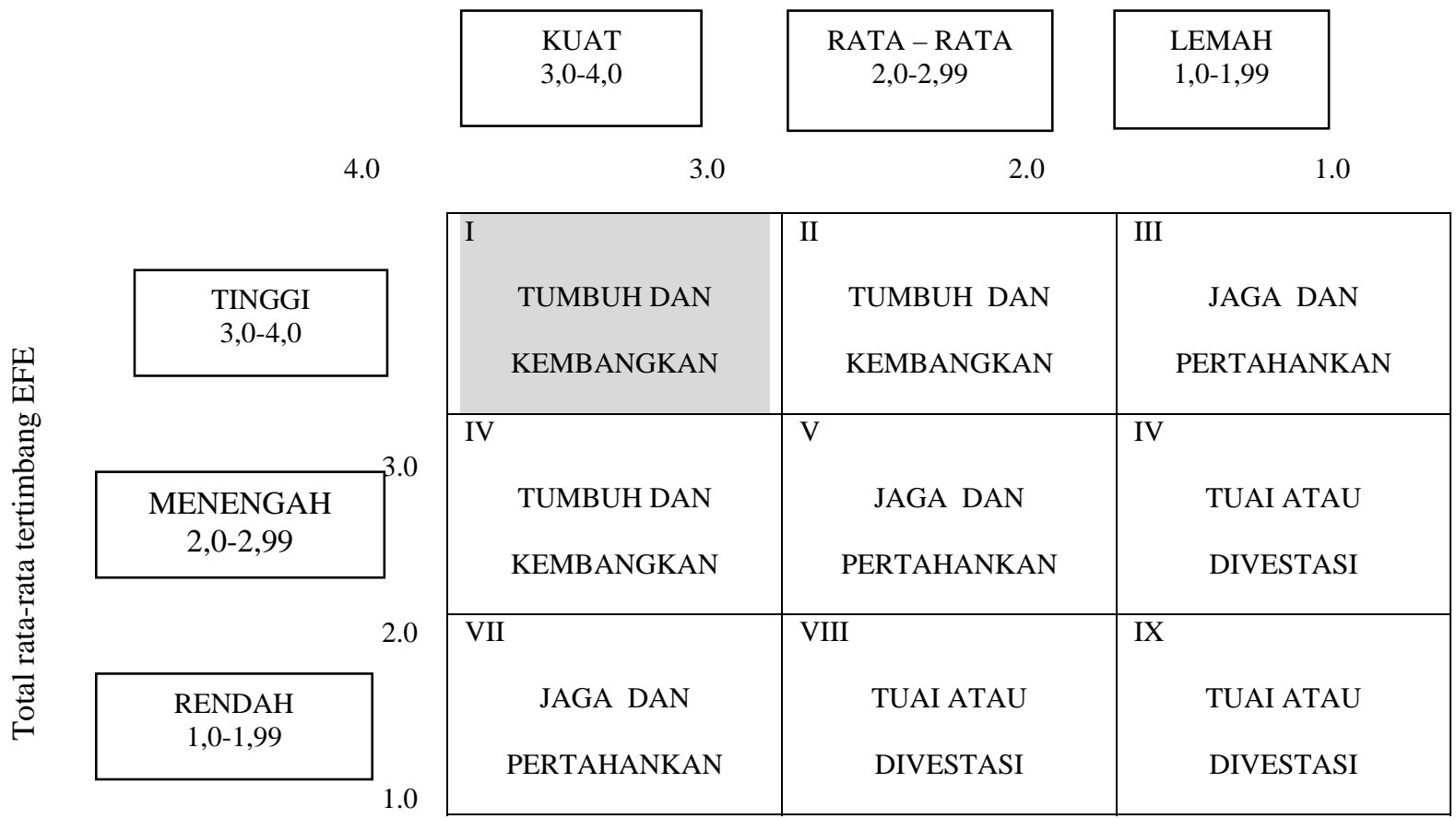

Gambar 1 Matriks Internal-Eksternal SubDit PSI PT PLN

\section{Usulan Pemecahan Masalah}

Berdasarkan hasil analisis, baik secara internal maupun eksternal dapat diperoleh beberapa pemecahan masalah untuk SubDit PSI atas sistem pengadaan (e-procurement). Hasilnya adalah sebagai berikut.

\section{Arahan Strategi}

Tabel 2 Arahan Strategi SubDit PSI

\begin{tabular}{|c|c|c|c|c|}
\hline Arahan strategi & Tujuan & Metriks & & Bobot \\
\hline $\begin{array}{l}\text { 1. Fokus pada pengembangan } \\
\text { inovasi e-Proc }\end{array}$ & $\begin{array}{l}\text { - Meningkatkan pendapatan } \\
\text { PLN } \\
\text { - Menyediakan target pasar } \\
\text { yang tepat bagi perusahaan } \\
\text { rekanan }\end{array}$ & $\begin{array}{l}\checkmark \text { Profit PLN } \\
\checkmark \text { Peringkat situs } \\
\text { pln.co.id }\end{array}$ & $30 \%$ & $45 \%$ \\
\hline $\begin{array}{l}\text { 2. Memperluas jaringan rekanan } \\
\text { PLN atau penyedia barang/jasa } \\
\text { di seluruh Indonesia dengan } \\
\text { dukungan teknologi }\end{array}$ & $\begin{array}{l}\text { - Meningkatkan hubungan } \\
\text { dengan rekanan PLN } \\
\text { - Menyebarkan informasi } \\
\text { pengadaan kepada rekanan } \\
\text { yang terdaftar di PLN }\end{array}$ & $\begin{array}{l}\checkmark \text { Jumlah pengadaan } \\
\text { yang berhasil } \\
\checkmark \text { Jumlah } \\
\text { pengumuman yang } \\
\text { diterima rekanan }\end{array}$ & $25 \%$ & $30 \%$ \\
\hline $\begin{array}{l}\text { 3. Fokus pada kebutuhan user } \\
\text { eksternal }\end{array}$ & $\begin{array}{l}\text { - Fokus pada pelayanan yang } \\
\text { optimal- peningkatan } \\
\text { pelatihan user eksternal } \\
\text { - Meningkatkan jumlah } \\
\text { rekanan PLN }\end{array}$ & $\begin{array}{l}\checkmark \text { Jumlah keluhan } \\
\text { yang diterima via } \\
\text { Help Desk } \\
\checkmark \text { Jumlah rekanan } \\
\quad \text { PLN yang terdaftar }\end{array}$ & $10 \%$ & $25 \%$ \\
\hline
\end{tabular}




\section{Proyek}

Adalah proyek-proyek yang akan dilakukan oleh perusahaan, yang mana akan ditujukan bagi user dalam mendukung kegiatan operasionalnya dan juga meningkatkan nilai tambah bagi pihak internal dan eksternal dalam praktik pengadaan.

Tabel 3 Portfolio Proyek

\begin{tabular}{lrcrc}
\hline \multicolumn{1}{c}{ Nama proyek } & Dampak & Resiko & Biaya (Juta Rp ) & Portfolio \\
\hline e-marketing & 467 & 33,2 & 500 & Strategic \\
SMS Mobile & 411 & 46,2 & 1650 & Strategic \\
Help Desk Online & 254 & 29,8 & 800 & Strategic \\
\hline
\end{tabular}

Berdasarkan pada Tabel 2, perusahaan dapat menentukan tindakan manajemen dengan strategi investasi atas dampak dan resiko di masing-masing proyek perusahaan. Berikut ini adalah informasi mengenai proyek yang akan dijalankan.

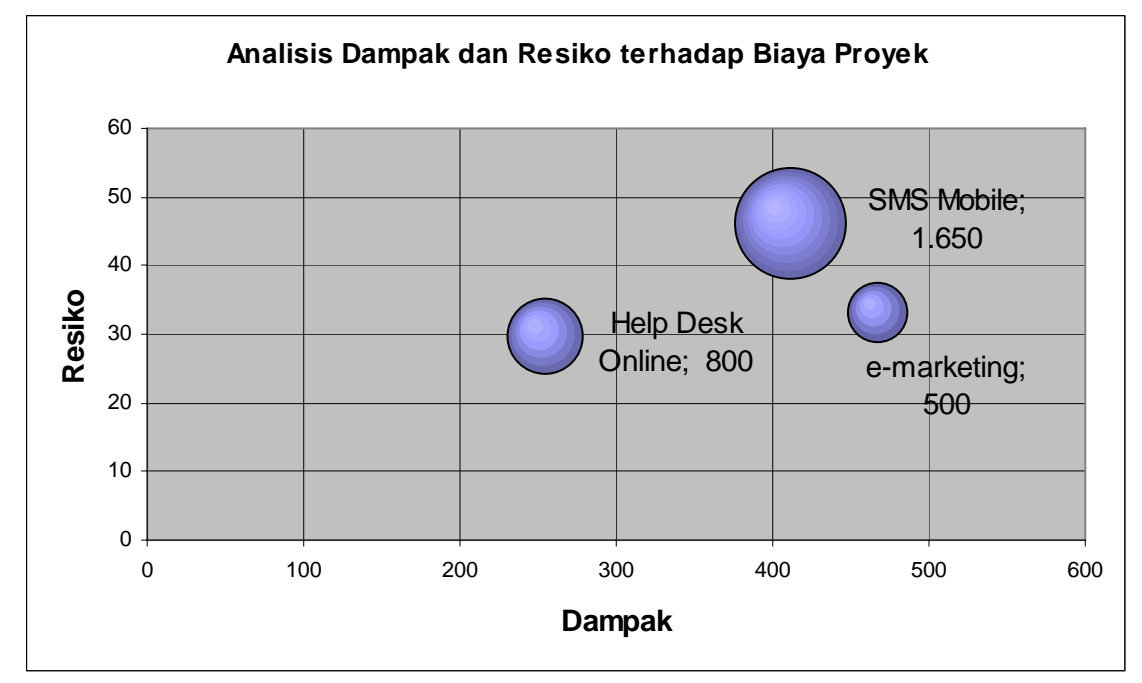

Gambar 2 Analisis Dampak dan Resiko Proyek terhadap Biaya

Informasi dari gambar di atas adalah bahwa untuk proyek yang diprioritaskan adalah proyek yang memiliki dampak terbesar. Adapun proyek yang diutamakan atau terlebih dahulu dijalankan adalah proyek e-marketing, yang memiliki dampak sebesar 467 dengan resiko sebesar 33,2. Sedangkan besarnya biaya proyek ditunjukkan oleh besarnya lingkaran, yaitu sebesar 500 juta. 


\section{Strategi Investasi Sistem Informasi yang Sedang Berjalan}

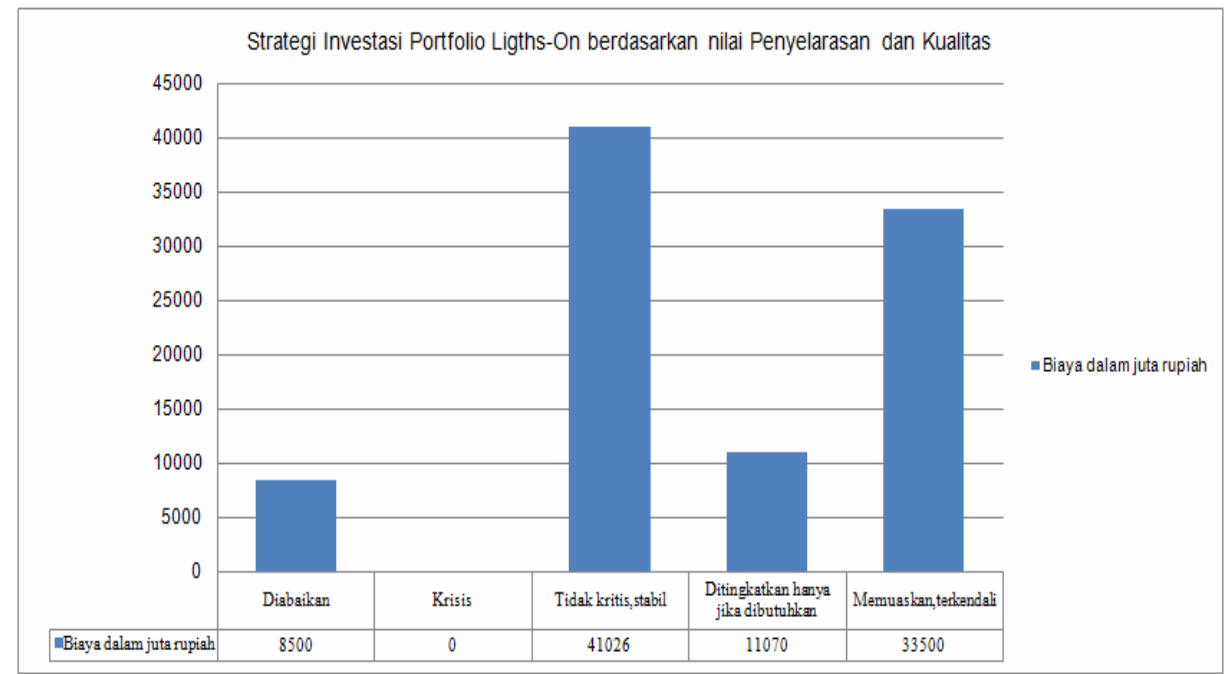

Gambar 3 Strategi Investasi Sistem Informasi yang Sedang Berjalan

Dari gambar di atas dapat diketahui: untuk kategori diabaikan, biaya yang dibutuhkan adalah sebesar 8500 juta rupiah, sedangkan yang termasuk dalam kategori ini adalah SAP Modul Huma Resource Management. Untuk kategori tidak kritis,stabil, biaya yang dikeluarkan adalah sebesar 41026, sedangkan yang termasuk dalam kategori ini adalah Portal e-proc, SAP Modul Material management, SAP Modul Finance Management, Maintenance, SLA. Untuk kategori ditingkatkan hanya jika dibutuhkan, biaya yang dikeluarkan adalah sebesar 11070, sedangkan yang termasuk dalam kategori ini adalah Helpdesk and technical support, Pendidikan dan pelatihan,Management TI, Pengembangan aplikasi, Pengadaan Annual Technical Support. Untuk kategori memuaskan,terkendali, biaya yang dikeluarkan adalah sebesar 33500 juta rupiah, yang termasuk dalam kategori ini adalah Network, Hardware, dan Database. Untuk kategori krisis "tidak ada”.

\section{Hubungan Kualitas, Penyelarasan, dan Ketergantungan}

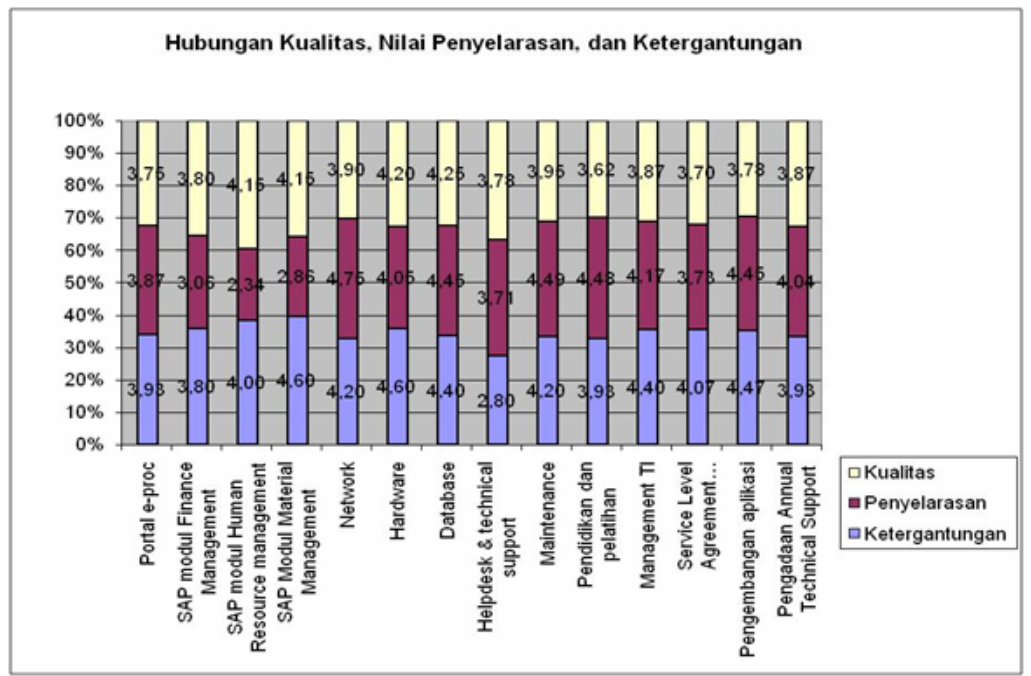

Gambar 4 Strategi Investasi Sistem Informasi yang Sedang Berjalan 
Gambar di atas dapat disimpulkan bahwa semakin tinggi nilai ketergantungan, maka sistem aplikasi maka sistem aplikasi semakin dibutuhkan oleh perusahaan, semakin tinggi nilai penyelarasan strategi maka sistem aplikasi tersebut semakin sesuai dengan strategi bisnis perusahaan dan semakin tinggi nilai kualitas maka kinerja sistem tersebut semakin baik. Penjelasan rincinya yaitu.

Portal e-Proc memiliki tingkat ketergantungan tinggi dengan nilai 3,93, nilai penyelarasan strategi yang sedang yaitu 3,87 dan nilai kualitas yang sedang yaitu 3.75. SAP Modul Finance Management, memiliki tingkat ketergantungan tinggi dengan nilai 3,80, nilai penyelarasan strategi yang sedang yaitu 3.06 dan nilai kualitas yang tinggi yaitu 3,80. SAP Modul Human Resource, memiliki tingkat ketergantungan sedang dengan nilai 4,00, nilai penyelarasan strategi yang sedang yaitu 2,34 dan nilai kualitas yang rendah yaitu 4,15. SAP Modul Material Management, memiliki tingkat ketergantungan sedang dengan nilai 4,60, nilai penyelarasan strategi yang sedang yaitu 2,86 dan nilai kualitas yang sedang juga yaitu 4,15.

Network memiliki tingkat ketergantungan sedang dengan nilai 4,20, nilai penyelarasan strategi yang sedang yaitu 4,75 dan nilai kualitas yang sedang juga yaitu 3,90. Hardware, memiliki tingkat ketergantungan sedang dengan nilai 4,60 , nilai penyelarasan strategi yang sedang yaitu 4,05 dan nilai kualitas yang sedang juga yaitu 4,20. Database memiliki tingkat ketergantungan tinggi dengan nilai 4,40, nilai penyelarasan strategi yang sedang yaitu 4,45 dan nilai kualitas yang tinggi yaitu 4,25. Helpdesk and Technical Support memiliki tingkat ketergantungan tinggi dengan nilai 2,80, nilai penyelarasan strategi yang sedang yaitu 3,71 dan nilai kualitas yang tinggi yaitu 3,78.

Maintenance memiliki tingkat ketergantungan tinggi dengan nilai 4,20, nilai penyelarasan strategi yang sedang yaitu 4,49 dan nilai kualitas yang tinggi yaitu 3,95. Pendidikan dan pelatihan memiliki tingkat ketergantungan tinggi dengan nilai 3,93, nilai penyelarasan strategi yang sedang yaitu 4,48 dan nilai kualitas yang tinggi yaitu 3,62. Management TI memiliki tingkat ketergantungan tinggi dengan nilai 4,40, nilai penyelarasan strategi yang sedang yaitu 4,17 dan nilai kualitas yang tinggi yaitu 3,87. Service level agreement memiliki tingkat ketergantungan tinggi dengan nilai 4,07, nilai penyelarasan strategi yang sedang, yaitu 3,73 dan nilai kualitas yang tinggi, yaitu 3,70. Pengembangan aplikasi memiliki tingkat ketergantungan tinggi dengan nilai 4,47, nilai penyelarasan strategi yang sedang yaitu 4,45 dan nilai kualitas yang tinggi yaitu 3,78. Pengadaan Annual technical support memiliki tingkat ketergantungan tinggi dengan nilai 3,93, nilai penyelarasan strategi yang sedang yaitu 4,04 dan nilai kualitas yang tinggi yaitu 3,87.

\section{SIMPULAN}

Berdasarkan penelitian dan analisis hasil penelitian yang dilakukan, maka dapat diambil beberapa kesimpulan, antara lain: pertama, arahan strategi yang dapat dilakukan perusahaan untuk memperbaiki dampak garis bawah agar perusahaan dapat mempertahankan posisi yaitu dengan menerapkan arahan strategi: fokus pada pengembangan inovasi e-Proc, memperluas jaringan rekanan PLN atau penyedia barang dan jasa di seluruh Indonesia dengan dukungan teknologi, fokus pada kebutuhan user eksternal.

Kedua, perencanaan kebutuhan investasi SI dan TI di masa depan dapat dilihat dari arahan strategi yang ada berdasarkan demand/supply planning, innovation, strategic IT requirement. Dari hasil analisis tersebut diperoleh tiga proyek, yakni e-marketing, SMS Mobile, dan Helpdesk Online. Yang mana setelah dianalisa proyek yang dapat didahulukan berdasarkan prioritization dalam menggunakan metoda NIE adalah Proyek e-marketing yang mana memberikan dampak yang besar dan resiko yang diberikan juga lebih kecil dibandingkan proyek SMS Mobile. Ketiga, investasi yang dikeluarkan oleh perusahaan dapat dilihat dari portfolio lights on yang ada dimana, berdasarkan hasil 
analisis hubungan kualitas dan nilai penyelarasan maka diperoleh: untuk kategori "Tidak kritis, Stabil”, yang terdiri dari Portal e-Proc, SAP Modul Finance Management, SAP Modul Material Management, Service Level Agreement, Maintenance, untuk kategori "Ditingkatkan hanya jika dibutuhkan” yang terdiri dari Helpdesk dan Technical Support, Pengadaan Annual technical Support, Pengembangan aplikasi, Management TI, Pendidikan dan pelatihan, untuk kategori ” Memuaskan , Terkendali”, yang terdiri dari Network, Hardware, Database, untuk kategori “ Diabaikan” terdiri dari SAP Modul Human Resource Management.

\section{DAFTAR PUSTAKA}

Anonim1. (2009). Seputar e-procurement. Diakses tanggal 3 September 2009 dari http://www.ebizzasia.com.

Anonim2. (2009). Diakses tanggal 11 September 2009 dari http://portal.pengadaannasionalbappenas.go.id/index.php/unduh-berkas/category/15-buku-artikelumum?download=79\%3Adasar-prinsip-teknik-dan-potensi-pengembangan-e-procurement.

Anonim3. (2010). Diakses tanggal 18 Januari 2010 dari http://www.mdbegp.org/www/eGPInteractiveus/tabid/69/language/en-US/Default.aspx.

Benson, R. J., Thomas L. B., and William B. W. (2004). From business strategy to TI action. Right decisions for a better bottom line, New Jersey: John Wiley and Sons, Inc.

David, F. R. (2004). Manajemen strategis: Konsep-konsep, edisi kesembilan, Jakarta: PT Indeks Kelompok Gramedia.

Davila, A., Gupta, M., Palmer, R. J. (2002). Moving procurement systems to the internet: The adoption and use of e-procurement technology models. Stanford GSB Research Paper No. 1742.

Turban, E. (2004). Electronic commerce 2004: A managerial perspective, New Jersey: Pearson Prentice Hall. 